\title{
ANTIMICROBIAL SUSCEPTIBILITY PATTERN OF BACTERIAL AND FUNGAL OCULAR ISOLATES FROM TERTIARY CARE OPHTHALMIC HOSPITALS IN CHENNAI
}

\author{
Senthilvadivu $C^{1}$, Stalin $M^{2}$
}

${ }_{1}^{1}$ Assistant Professor, Department of Microbiology, Government Dharmapuri Medical College, Dharmapuri, Tamilnadu.

2Tutor, Department of Microbiology, Government Dharmapuri Medical College, Dharmapuri, Tamilnadu.

\section{ABSTRACT}

\section{BACKGROUND}

Infectious keratitis is an ophthalmic emergency that needs immediate institution of treatment. Recent studies have shown increasing evidence of resistance of microbes to antimicrobial agents, which have further added to the reasons for poor prognosis in microbial keratitis.

Aims and Objectives- This study was carried out to understand the antimicrobial susceptibility pattern of bacterial and fungal isolates in keratitis.

\section{MATERIALS AND METHODS}

A total of 150 corneal scraping samples were collected and identified by standard protocol and were tested for antibiotic susceptibility as per CLSI guidelines with various groups of antibiotics. MIC for vancomycin, amphotericin B and itraconazole were determined for study isolates by agar dilution method.

\section{RESULTS}

Out of 150 corneal scraping samples, 97 (64.6\%) showed culture positivity. Among bacterial, fungal and parasitic agents isolated fungi were the predominant aetiological agents. Staphylococcus aureus (26.4 \%), Aspergillus sp. and (24.8 \%) Acanthamoeba sp. were the most frequently isolated bacterial, fungal and protozoan aetiological agents respectively. Majority of the bacterial isolates were susceptible to amikacin $(94.1 \%)$ and were least susceptible to cotrimoxazole $(26.4 \%)$. All Staphylococcus sp. were found to be susceptible to vancomycin with MIC range of $0.25-0.5 \mu \mathrm{g} / \mathrm{mL}$. More than $50 \%$ of fungal isolates were susceptible to both amphotericin B and itraconazole and none of the fungal isolates were susceptible to fluconazole. About $85.9 \%$ of fungal isolates had MIC value of (MIC $<2 \mu \mathrm{g} / \mathrm{mL}$ ) for itraconazole.

\section{CONCLUSION}

This study suggests that the in vitro susceptibility testing of bacterial and fungal isolates of infectious keratitis is extremely useful in clinical management and should be performed as a routine diagnostic protocol.

\section{KEYWORDS}

Infectious Keratitis, Antimicrobial Susceptibility and MIC.

HOW TO CITE THIS ARTICLE: Senthilvadivu C, Stalin M. Antimicrobial susceptibility pattern of bacterial and fungal ocular isolates from tertiary care ophthalmic hospitals in Chennai. J. Evolution Med. Dent. Sci. 2018;7(15):1868-1871, DOI: $10.14260 /$ jemds/2018/421

\section{BACKGROUND}

Corneal ulcer or infectious keratitis is a serious condition of cornea that requires prompt management. It can be caused by bacteria, virus, fungus, protozoa and parasites. Varieties of antibiotics are available in the market for the treatment of ocular infections and administered by various routes including topical instillation, subconjunctival injection and intraocular injection of antibiotics. Eye drops are available in fortified forms to achieve higher concentration in ocular tissues. Antibiotic resistance among ocular pathogens is increasing in parallel with the increase of resistance in other systemic pathogens. The factors contributing to development of drug resistance among ocular isolates include overuse of

'Financial or Other Competing Interest': None.

Submission 27-02-2018, Peer Review 24-03-2018,

Acceptance 30-03-2018, Published 09-04-2018.

Corresponding Author:

Dr. Senthilvadivu $C$

Assistant Professor,

Department of Microbiology,

Government Dharmapuri Medical College,

Dharmapuri, Tamilnadu.

E-mail: ezhilan14@yahoo.com

DOI: $10.14260 /$ jemds $/ 2018 / 421$

antibiotics for systemic infection as well as overuse of topical antibiotics in the eye. ${ }^{1}$ If the appropriate antimicrobial treatment is delayed, only $50 \%$ of the eyes gain good visual recovery. ${ }^{2}$ Though the majority of community acquired cases of microbial keratitis resolves with empiric treatment and do not require culture, corneal scraping for culture and sensitivity is indicated for corneal ulcers that are unresponsive to broad-spectrum antibiotic therapy. ${ }^{3}$ Recent studies have shown increasing evidence of resistance of microbes to antimicrobial agents. ${ }^{1,4}$ Hence, knowledge of the microbiological pattern of bacterial and fungal keratitis will be helpful for effective management of keratitis in situations where resources are limited. Hence, this study was done to determine the antimicrobial susceptibility profiles of bacterial and fungal aetiological agents among patients with infective keratitis from a tertiary care Regional Institute of Ophthalmology and Rajiv Gandhi Government General Hospital in Chennai.

\section{MATERIALS AND METHODS}

A descriptive study was carried out over a period of one year from October 2011 to September 2012. A total of 150 corneal scraping samples were collected from patients presenting in the outpatient department with the history of trauma and 
signs and symptoms of infectious corneal ulcer. Bacterial, fungal and protozoan isolates were identified by standard protocol and were tested for antibiotic susceptibility by the Kirby-Bauer disc diffusion method on Mueller Hinton agar (HiMedia) and were interpreted in accordance with the CLSI guidelines. ${ }^{5}$ Methicillin resistance was detected by taking oxacillin disc $(1 \mu \mathrm{g})$ as a surrogate marker. Antibiogram was done with the following antibiotics: Amikacin (30 $\mu \mathrm{g})$, cefotaxime (30 $\mu \mathrm{g})$, chloramphenicol $(30 \mu \mathrm{g})$, ciprofloxacin (5 $\mu \mathrm{g})$, cotrimoxazole $(25 \mu \mathrm{g})$, erythromycin $(15 \mu \mathrm{g})$, imipenem $(10 \mu \mathrm{g})$, ofloxacin $(5 \mu \mathrm{g})$ and penicillin $\mathrm{G}(10 \mathrm{U})$. MIC for vancomycin was determined by agar dilution method as per CLSI guidelines. ${ }^{5}$ Antifungal susceptibility disc diffusion test was performed on Mueller-Hinton agar plates supplemented with $2 \%$ Glucose and $0.5 \mu \mathrm{g} / \mathrm{mL}$ of methylene blue and the following antifungal agents: Amphotericin B (100 U), itraconazole $(10 \mu \mathrm{g})$ and fluconazole $(10 \mu \mathrm{g})$. MIC for amphotericin $\mathrm{B}$ and itraconazole were determined by agar dilution method. The reference strains used were Staphylococcus aureus ATCC 25923, Escherichia coli ATCC 25922, Aspergillus flavus ATCC 204304 and Aspergillus fumigatus ATCC 204305.

\section{RESULTS}

Out of 150 corneal scrapings, 97 (64.6\%) samples were found to be culture positive. Among bacterial, fungal and parasitic agents isolated, fungi $57(38 \%)$ were the predominant aetiological agent. Staphylococcus aureus (26.4\%), Aspergillus $s p$. (24.8\%) were the most frequently isolated among bacterial and fungal agents respectively and Acanthamoeba $s p$. was the only parasitic agent isolated in infectious keratitis (Table 1). Majority of the bacterial isolates were susceptible to amikacin $(94.1 \%)$ followed by ciprofloxacin $(82.3 \%)$, cefotaxime $(79.4 \%)$, ofloxacin $(61.7 \%)$ and were least susceptible to gentamicin $(44.1 \%)$ and cotrimoxazole
(26.4\%) (Table 2). Methicillin resistance was observed among S. aureus $2 / 9$ (22.2\%) and S. epidermidis $2 / 6$ (33.3\%). All Staphylococcus sp. were found to be susceptible to vancomycin by agar dilution method with MIC range of 0.25 $0.5 \mu \mathrm{g} / \mathrm{mL}$. More than $50 \%$ of fungal isolates were susceptible to both amphotericin B and itraconazole and none of the fungal isolates were susceptible to fluconazole (Table 3) and (Plate No. 1). More than $66 \%$ of fungal isolates had MIC value of (MIC $<2 \mu \mathrm{g} / \mathrm{mL}$ ) for amphotericin B (Table 4). Out of 59 , $47(85.9 \%)$ fungal isolates had MIC value of (MIC $\leq 2 \mu \mathrm{g} / \mathrm{mL})$ for itraconazole by agar dilution method (Table 5).

\begin{tabular}{|c|c|}
\hline Bacterial Agents & No. of Isolates (\%) \\
\hline Staphylococcus aureus & $9(26.4 \%)$ \\
\hline Staphylococcus epidermidis & $6(17.6 \%)$ \\
\hline Pseudomonas aeruginosa & $6(17.6 \%)$ \\
\hline Klebsiella pneumoniae & $5(14.7 \%)$ \\
\hline Acinetobacter baumannii & $4(11.7 \%)$ \\
\hline Escherichia coli & $4(11.7 \%)$ \\
\hline Total & $34(100 \%)$ \\
\hline \multicolumn{2}{|c|}{ Fungal Agents } \\
\hline Aspergillus flavus & $14(24.5 \%)$ \\
\hline Aspergillus niger & $12(21 \%)$ \\
\hline Aspergillus fumigatus & $10(17.5 \%)$ \\
\hline Fusarium spp. & $12(21 \%)$ \\
\hline Curvularia spp. & $2(3.5 \%)$ \\
\hline Penicillium spp. & $3(5.2 \%)$ \\
\hline Graphium spp. & $2(3.5 \%)$ \\
\hline Scopulariopsis spp. & $2(3.5 \%)$ \\
\hline Total & $57(100 \%)$ \\
\hline \multicolumn{2}{|c|}{ Parasitic Agents } \\
\hline Acanthamoeba spp. & $6(100 \%)$ \\
\hline $\begin{array}{r}\text { Table 1. Distribution of } B \\
\text { Agents among Infec }\end{array}$ & $\begin{array}{l}\text { l, Fungal and Parc } \\
\text { Keratitis Patients }\end{array}$ \\
\hline
\end{tabular}

\begin{tabular}{|c|c|c|c|c|c|c|c|c|c|c|c|c|c|c|c|c|c|c|c|}
\hline \multirow{2}{*}{\begin{tabular}{|l|}
\multicolumn{1}{|c|}{ Organism } \\
$\begin{array}{l}\text { Staphylococcus. } \\
\text { aurews }\end{array}$ \\
\end{tabular}} & \multirow{2}{*}{$\begin{array}{c}\begin{array}{c}\text { Total } \\
\text { No. }\end{array} \\
9 \\
\end{array}$} & \multicolumn{2}{|c|}{ Amikacin } & \multicolumn{2}{|c|}{ Gentamicin } & \multicolumn{2}{|c|}{ Ciprofloxacin } & \multicolumn{2}{|c|}{ Ofloxacin } & \multicolumn{2}{|c|}{ Cefataxime } & \multicolumn{2}{|c|}{ Cotrimoxazole } & \multicolumn{2}{|c|}{ Cephalexin } & \multicolumn{2}{|c|}{ Vancomycin } & \multicolumn{2}{|c|}{ Oxacillin } \\
\hline & & 9 & $100 \%$ & - & - & 7 & $77 \%$ & 7 & $77 \%$ & 8 & $88 \%$ & 5 & $55.5 \%$ & 7 & $77 \%$ & 9 & $100 \%$ & 7 & $77 \%$ \\
\hline $\begin{array}{l}\text { Staphylococcus. } \\
\text { epiderwidis }\end{array}$ & 6 & 6 & $100 \%$ & . & - & 6 & $100 \%$ & - & - & 6 & $100 \%$ & 4 & $66 \%$ & 4 & $66 \%$ & 6 & $100 \%$ & 4 & $66 \%$ \\
\hline $\begin{array}{l}\text { Psendomonas } \\
\text { aenuginosa }\end{array}$ & 6 & 6 & $100 \%$ & 5 & $83 \%$ & 4 & $66 \%$ & 5 & $83 \%$ & 4 & $66 \%$ & . & - & 5 & $83 \%$ & $\cdot$ & - & $\cdot$ & - \\
\hline $\begin{array}{l}\text { Klebsiella } \\
\text { pneumoniae }\end{array}$ & 5 & 5 & $100 \%$ & 4 & $80 \%$ & 5 & $100 \%$ & 4 & $80 \%$ & 3 & $60 \%$ & - & - & 4 & $80 \%$ & $\cdot$ & - & - & - \\
\hline $\begin{array}{l}\text { Acinetobacter } \\
\text { boumanii }\end{array}$ & 4 & 3 & $75 \%$ & 3 & $75 \%$ & 2 & $50 \%$ & 2 & $50 \%$ & 3 & $75 \%$ & - & - & 3 & $75 \%$ & - & - & - & - \\
\hline $\begin{array}{l}\text { Escherichia } \\
\text { coli }\end{array}$ & 4 & 3 & $75 \%$ & 3 & $75 \%$ & 4 & $100 \%$ & 3 & $75 \%$ & 3 & $75 \%$ & - & - & 3 & $75 \%$ & - & - & - & - \\
\hline $\begin{array}{l}\text { Percentage of } \\
\text { Sensitivity }\end{array}$ & 34 & & $94.11 \%$ & & $44.11 \%$ & & $82.35 \%$ & & $61.76 \%$ & & $79.41 \%$ & & $26.47 \%$ & & $76.47 \%$ & & $100 \%$ & & $32.35 \%$ \\
\hline
\end{tabular}

Table 2. Antimicrobial Susceptibility Pattern of Bacterial Isolates of Infectious Keratitis 


\begin{tabular}{|l|c|c|c|c|}
\hline \multicolumn{1}{|c|}{ Agent } & $\begin{array}{c}\text { No.of } \\
\text { isolates }\end{array}$ & $\begin{array}{c}\text { Amphotericin- } \\
\mathbf{B}(\mathbf{2 0} \mathbf{\mu g}) \mathbf{S}>\mathbf{1 5} \\
\mathbf{m m}\end{array}$ & $\begin{array}{c}\text { Itraconazole } \\
(\mathbf{1 0 \mu \mathbf { g } )} \\
\mathbf{S}>\mathbf{2 3} \mathbf{~ m m}\end{array}$ & $\begin{array}{c}\text { Fluconazole } \\
(\mathbf{1 0 \mu \mathbf { g } )} \\
\mathrm{S}>\mathbf{1 9} \mathbf{~ m m}\end{array}$ \\
\hline $\begin{array}{l}\text { Aspergillus } \\
\text { flavus }\end{array}$ & 14 & $9(64 \%)$ & $11(78 \%)$ & $\mathrm{R}$ \\
\hline $\begin{array}{l}\text { Aspergillus } \\
\text { niger }\end{array}$ & 12 & $7(58 \%)$ & $12(100 \%)$ & $\mathrm{R}$ \\
\hline $\begin{array}{l}\text { Aspergillus } \\
\text { fumigatus }\end{array}$ & 10 & $7(70 \%)$ & $10(100 \%)$ & $\mathrm{R}$ \\
\hline $\begin{array}{l}\text { Fusarium spp } \\
\text { Curvularia spp }\end{array}$ & 12 & $8(66 \%)$ & $10(83 \%)$ & $\mathrm{R}$ \\
\hline Penicillium spp & 3 & $1(50 \%)$ & $1(50 \%)$ & $\mathrm{R}$ \\
\hline $\begin{array}{l}\text { Graphium } s p p \\
\text { Scopulariopsis } \\
\text { spp }\end{array}$ & 2 & $1(50 \%)$ & $2(100 \%)$ & $\mathrm{R}$ \\
\hline
\end{tabular}

Table 3. Antibiotic Susceptibility Pattern of Fungal Isolates by Disc Diffusion Method

\begin{tabular}{|l|c|c|c|c|c|c|c|c|c|}
\hline \multicolumn{1}{|c}{ Organism } & $\mathbf{0 . 2 5}$ & $\mathbf{0 . 5}$ & $\mathbf{1}$ & $\mathbf{2}$ & $\mathbf{4}$ & $\mathbf{8}$ & $\mathbf{1 6}$ & $\mathbf{3 2}$ & $\mathbf{6 4}$ \\
& $\mu \mathbf{g}$ & $\mu \mathbf{g}$ & $\mu \mathbf{g}$ & $\mu \mathbf{g}$ & $\mu \mathbf{g}$ & $\mu \mathbf{g}$ & $\mu \mathbf{g}$ & $\mu \mathbf{g}$ & $\mu \mathbf{g}$ \\
\hline Aspergillus Flavus & 3 & 2 & 5 & 2 & 1 & - & 1 & - & - \\
\hline Aspergillus niger & 2 & 3 & 3 & 1 & 1 & 1 & 1 & - & - \\
\hline $\begin{array}{l}\text { Aspergillus } \\
\text { Fumigatus }\end{array}$ & 1 & 3 & 1 & 2 & 1 & 1 & - & 1 & - \\
\hline Fusarium spp & 3 & 1 & 3 & 3 & 1 & 1 & - & - & - \\
\hline Curvularia spp & - & 1 & 1 & - & - & - & - & - & - \\
\hline Penicillium spp & - & 1 & 1 & - & 1 & - & - & - & - \\
\hline Graphium spp & - & 1 & 1 & - & - & - & - & - & - \\
\hline Scopulariopsis spp & - & - & 1 & 1 & - & - & - & - & - \\
\hline
\end{tabular}

Table 4. MIC for Amphotericin B by Agar Dilution Method

\begin{tabular}{|l|c|c|c|c|c|c|c|c|c|}
\hline \multicolumn{1}{|c|}{ Organism } & $\mathbf{0 . 2 5}$ & $\mathbf{0 . 5}$ & $\mathbf{1}$ & $\mathbf{2}$ & $\mathbf{4}$ & $\mathbf{8}$ & $\mathbf{1 6}$ & $\mathbf{3 2}$ & $\mathbf{6 4}$ \\
\hline Aspergillus Flavus & 3 & 4 & 2 & 4 & 1 & - & - & - & - \\
\hline Aspergillus niger & 2 & 3 & 2 & 3 & 1 & 1 & - & - & - \\
\hline $\begin{array}{l}\text { Aspergillus } \\
\text { Fumigatus }\end{array}$ & - & 2 & 3 & 2 & 1 & - & - & 1 & 1 \\
\hline Fusarium spp & 2 & 3 & 2 & 3 & 1 & 1 & - & - & - \\
\hline Curvularia spp & 1 & - & 1 & - & - & - & - & - & - \\
\hline Penicillium spp & 1 & - & 1 & 1 & - & - & - & - & - \\
\hline Graphium spp & - & 1 & 1 & - & - & - & - & - & - \\
\hline Scopulariopsis spp & - & - & 1 & 1 & - & - & - & - & - \\
\hline
\end{tabular}

\section{Table 5. MIC for Itraconazole by Agar Dilution Method}

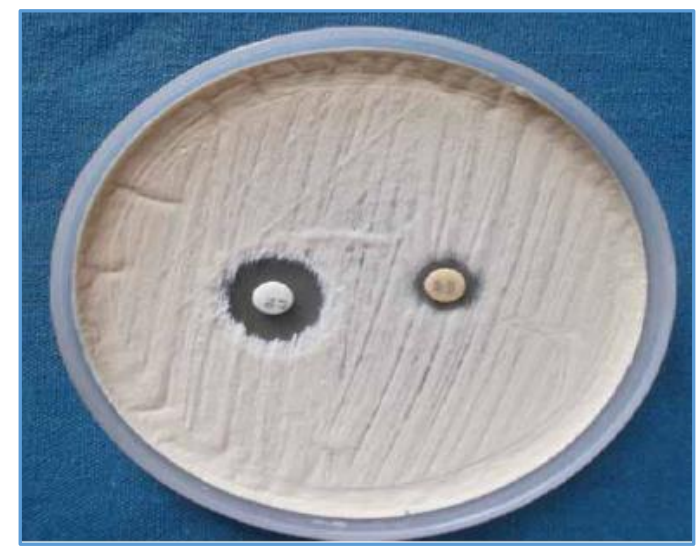

Plate No. 1. Antifungal Susceptibility by Disc Diffusion Method

\section{DISCUSSION}

Microbial resistance to antibiotic agents is becoming increasingly prevalent in ocular infections. Immediate diagnosis and treatment are important to avoid visionthreatening outcomes including corneal scarring or perforation. 6 The past two decades have witnessed changes in antibiotic susceptibility patterns on a worldwide basis. Guidelines that have been developed to help slow the escalation of systemic antibiotic resistance and encourage prudent use of antibiotic agents also apply to the management of ocular infections. In this study, fungal agents were the most common agents isolated in infectious keratitis patients followed by bacterial and parasitic agents. This is in accordance with a study by Khanal et al (2005) in Nepal who reported $42.7 \%$ culture positive for fungal agents. ${ }^{7}$ In this study, Aspergillus sp. was the predominant isolate $(63.1 \%)$ followed by Fusarium $s p$. (21\%) and this correlates with study from Hyderabad by Gopinathan et al (2002). ${ }^{8}$ Among the bacterial isolates Staphylococcus aureus 9 (27\%) was the most common bacterial agent isolated, which was similar to the study by Basak et al (2005) who reported that Staphylococcus aureus was the most common bacterial isolate. ${ }^{9}$ Among the parasitic agents protozoa like Acanthamoeba sp. was isolated in 6 patients $(6.3 \%)$ and this was the only parasitic agent isolated. Corneal infection due to Acanthamoeba is believed to result from direct corneal contact with contaminated material or water. Various Indian studies show prevalence rate of $1 \%$ to $4 \%$ Acanthamoeba culture positive corneal ulcers. ${ }^{10}$ Amikacin was found to be the most effective antibiotic (94.1\%) for the bacterial isolates in this study. This coincides with a study by Fong et al (2007). ${ }^{11}$ Susceptibility to ofloxacin and gentamicin antibiotics were comparatively lower in this study indicating the selective usage for the treatment in the study sites. In this study, $22.2 \%$ of $S$. aureus isolates were found to be methicillin resistant. In this study both gram positive and gram negative bacterial isolates showed susceptibility to amikacin, which was similar to the study report of Kaliamurthy et al (2013). ${ }^{12}$ High percentages of fungal isolates were susceptible to both amphotericin B and itraconazole in this study suggesting that they have effective role in management of fungal keratitis. Alarmingly, all the fungal isolates were found to be resistant to fluconazole, indicating no longer it can be used for the empirical therapy. Management of fungal keratitis remains a challenge to cornea specialists. Current selection of antifungals is based on animal experiments, clinical experience and published sensitivity data. In vitro sensitivity testing of a particular isolate is extremely useful and should be performed whenever its availability is not a concern. ${ }^{13}$ In this study, majority of fungal isolates $(66 \%)$ had MIC value of $(<2 \mu \mathrm{g} / \mathrm{mL})$ for amphotericin B and $85.9 \%$ of fungal isolates had MIC value of $(\leq 2 \mu \mathrm{g} / \mathrm{mL})$ for itraconazole, strongly suggesting that it has a vital role in management of fungal keratitis.

\section{CONCLUSION}

This study suggests that emerging fungal pathogens and resistance to existing antifungal drugs demand the importance of antifungal susceptibility testing to manage fungal keratitis and the clinicians should prescribe antibiotic agents only when clearly indicated and should order susceptibility testing whenever possible to prescribe the 
most appropriate antibiotic to avoid development of antibiotic resistance.

\section{REFERENCES}

[1] Fintelmann RE, Hoskins EN, Leitman TM, et al. Topical fluoroquinolone use as a risk factor for in vitro fluoroquinolone resistance in ocular cultures. Arch Ophthalmol 2011;129(4):399-402.

[2] Jones DB. Decision-making in the management of microbial keratitis. Ophthalmology 1981;88(8):81420.

[3] Cornea/External disease panel preferred practice pattern guidelines, bacterial keratitis-limited revision, San Francisco, Calif, USA, American Academy of Ophthalmology, 2011.

[4] Wong RL, Gangwani RA, Yu LW, et al. New treatments for bacterial keratitis. Article ID 831502, J Ophthalmology 2012;2012:1-7.

[5] Clinical and Laboratory Standards Institute Performance standards for antimicrobial susceptibility testing. Approval standard M100-S17. CLSI, Wayne, PA, 2007.

[6] Pachigolla G, Blomquist P, Cavanagh HD. Microbial keratitis pathogens and antibiotic susceptibilities: a 5year review of cases at an urban county hospital in north Texas. Eye and Contact Lens 2007;33(1):45-9.
[7] Khanal B, Deb M, Panda A, et al. Laboratory diagnosis in ulcerative keratitis. Ophthal Res 2005;37(3):123-7.

[8] Gopinath U, Garg F, Fernandes M, et al. The epidemiological features and laboratory results of flingal keratitis: a 10 years review at a referral eye care center in south India. Cornea 2002;21:555-9.

[9] Basak SK, Basak S, Mohanta A, et al. Epideiniological and microbiological diagnosis of suppurative keratitis in Gangetic West Bengal, eastern India. Indian J Ophthalmol 2005;53(1):17-22.

[10] Manikandan P, Baskar M, Revathy R, et al. Acanthamoeba keratitis: a six year epidemiological review from a tertiary care eye hospital in south India. Indian J Med Microbiol 2006;22:226-30.

[11] Fong $\mathrm{CF}, \mathrm{Hu} \mathrm{FR}$, Tseng $\mathrm{CH}$, et al. Antibiotic susceptibility of bacterial isolates from bacterial keratitis cases in a university hospital in Taiwan. American J Opthalmol 2007;144(5):682-9.

[12] Kaliamurthy J, Kalavathy CM, Parmar P, et al. Spectrum of bacterial keratitis at a tertiary eye care centre in India. Article ID 181564, BioMed Research International 2013;2013:1-8.

[13] Maharana PK, Sharma N, Nagpal R, et al. Recent advances in diagnosis and management of Mycotic Keratitis. Indian J Ophthalmol 2016;64(5):346-57. 